realization follows that although every source of published knowledge, including the major contributions of the two authors and their pupils, has been utilized, yet a notable proportion of this book, including very many of the illustrations, consists of hitherto unpublished observations.

The third section of the book deals with ecology and is concerned with the limpets, whelks and tingle and other prosobranchs of rocky shores, with those of other marine habitats, with prosobranch inhabitants of brackish and fresh-waters and of the land, and finally with the parasites of these animals. It is our good fortune that the very occasional appearance of the heteropod Carinaria and more frequent appearance of Ianthina brings both these pelagic molluses within the British fauna and so within the scope and detailed description of these authors. We are also fortunate in possessing an interesting range of estuarine and fresh-water prosobranchs and even two terrestrial species, one of which the apple shell, Pomatias, receives particular and most welcome attention.

It is only in the Neritacea that the British fauna, with its solitary fresh-water representative, Theodoxus, is seriously lacking. The presence of some of the marine and terrestrial representatives so abundant in warmer latitudes would have been welcome because of the treatment they would here have received with perhaps the conclusion that these animals should be removed from the Archæogastropoda (or Diotocarida, as here preferred) to constitute an order of similar standing to the Mesogastropoda (Monotocardia).

The final section deals with relationships of the Prosobranchia with an appendix on classification and another containing a habitat and distribution list. This is followed by 37 pages of references.

No comparable book on the Mollusca has been published in our time (Thiele's great hand-book is in a different category). This is functional morphology at its best. Every malacologist in every countrybecause its scope far transcends the British faunashould possess this book. It is infinitely revealing in its descriptions of the elaborate intricacy, above all in the buccal and deeper alimentary systems and in the reproductive system, with their remarkable evolutionary developments.

I have read carefully through this very long book and find no cause for significant criticism and only one mistake-a reference on page 10 to cuttlefish where octopods are clearly meant. C. M. YoNGE

\section{THE COMPANY OF MINERAL AND BATTERY WORKS}

\section{Elizabethan Monopolies}

The History of the Company of Mineral and Battery Works from 1565 to 1604 . By Prof. M. B. Donald. Pp. $\mathrm{xv}+256+10$ plates. (Edinburgh and London: Oliver and Boyd, Ltd., 1961.) 50s. net.

T

HE introduction of a new source of power has always resulted in technical advances, but the changeover inevitably involves the design and manufacture of the necessary machinery the cost of which implies the raising of adequate capital. The sixteenth century was such a time of marked development in the utilization of water-power, particularly in the mechanisms necessary for its conversion to industrial use in, for example, providing the air blast for furnaces, operating stamp mills for the crushing of ore or in pumping water from the mines themselves.
The capital required ultimately reached proportions so high as no longer to be within the scope of the individual, and associations of a number of persons became essential. Two such partnership companies were formed in Elizabethan England, both concerned with the manufacture of metals and the products produced from them. Both the Company of Mines Royal and the Company of Mineral and Battery Works received their royal charters in 1568 , and it is with the second, and smaller, of these that the present work is mainly concerned. Unlike the Mines Royal, the eapital was raised entirely in Great Britain, and whereas that body was concerned chiefly with the production of copper in Cumberland, the Mineral and Battery Works had three fields of interest-lead in north Derbyshire, iron, largely for the production of wire, near Tintern Abbey, and brass at Isleworth in Middlesex. This range of activity proved too extensive to be controlled by any one of those concerned, and this, together with the technical failure at first to produce brass of sufficient ductility to be 'battered' into the required shapes, rendered it easier to run the partnership as a licensing company drawing its income from royalties paid by licensees operating the processes for which the Company held patents.

Since the formation and development of these two Companies are the roots of all future company law and procedure - and not only in Great Britain - the main emphasis of Prof. Donald's book is on the legal and commercial sides, though there are inevitably excursions into the technology of the time which add to our knowledge of the history of metallurgy in England and Wales at a critical period in its development.

The story is one of continual quarrels and law-suits which later played no small part in restraining the Royal prerogative to grant monopolies and patents. It is a story well worth telling, and it is well told, though one would like the evidence for the statements on page 96 that at that date "The phosphorus content" of iron "could be controlled by using limestone to give a basic slag to remove it as phosphate" and that "The sulphur content was controlled by selecting ores containing manganese ...". F. C. THOMPson

\section{HIPPED-PLATE AND THIN SHELL STRUCTURES IN ENGINEERING}

\section{Hipped-Plate (Folded Plate) Structures}

Their Theory and Analysis. By Joachim Born. Translated by C. V. Amerongen. Pp. ix + 250. (London: Crosby Lockwood and Son, Ltd., 1962.) 63s. net.

\section{Theory of Elastic Thin Shells}

By A. L. Gol'denvoizer. Translated, from the Russian and edited by G. Herrmann. (International Series of Monographs on Aeronautics and Astronautics. Division 1: Solid and Structural Mechanics, Vol. 2.) Pp. xxi+658. (London and New York: Pergamon Press, 1961.) 105s. net.

THE literature on hipped-plate or folded-plate structures, as such, is not very extensive although, in recent years, quite a number of papers have appeared in the technical press. The book by Born is, therefore, welcome in that it presents a thorough study of what is a specialized branch of structural engineering

The first part of the book deals with the analysis of prismatic hipped-plate structures. Initially, the analysis is based on the assumption that the junctions 